\title{
A legal framework with scientific basis for applying the 'polluter pays principle' to soil conservation in rural watersheds in Brazil
}

\author{
C.A. Valera ${ }^{\mathrm{a}, \mathrm{b}}$, T.C.T. Pissarra ${ }^{\mathrm{b}}$, M.V. Martins Filho ${ }^{\mathrm{b}}$, R.F. Valle Junior ${ }^{\mathrm{c}}$, L.F. Sanches Fernandes ${ }^{\mathrm{d}}$, \\ F.A.L. Pacheco*,e \\ a Promotoria de Justiça do Ministério Público do Estado de Minas Gerais, Brazil \\ b UNESP-Universidade Estadual Paulista, Campus de Jaboticabal, Estado de São Paulo, Brazil \\ c Instituto Federal do Triângulo Mineiro, Uberaba, Estado de Minas Gerais, Brazil \\ d Centro de Investigação e Tecnologias Agroambientais e Biológicas, Universidade de Trás-os-Montes e Alto Douro, Ap 1013, 5001-801, Vila Real, Portugal \\ e Centro de Química de Vila Real, Universidade de Trás-os-Montes e Alto Douro, Ap 1013, 5001-801, Vila Real, Portugal
}

\section{A R T I C L E I N F O}

\section{Keywords:}

Soil erosion

Degraded area

Environmental damage

Law

Legal responsibility

Geographic information system

\begin{abstract}
A B S T R A C T
The "polluter pays principle" (PPP) has been looked at from the perspective of legal values and technical principles, namely of soil science, to evaluate the acceleration of soil erosion and the consequent development of degraded areas in the Uberaba River basin (area: $2419 \mathrm{~km}^{2}$ ), state of Minas Gerais, Brazil. Having accomplished this goal, the study highlights the importance of PPP for the conservation of soil and development of an ecologically equilibrated environment. The diagnosis of degraded areas was based on the coupling of a Geographic Information System with soil loss, land use conflict and tolerance to soil loss models, and revealed a preoccupying situation because an extension of approximately $905 \mathrm{~km}^{2}$ (1/3 of the basin) has been considered in advanced state of degradation potentially causing environmental damage (e.g., decline of soil fertility and hence crop production, negative impacts of soil particles export on stream and lake water quality and biodiversity of riverine ecosystems). Facing this problem, a legal framework standing on doctrinaire principles, federal laws and the Brazilian Constitution has been proposed whereby the protagonists of soil degradation are called to assume responsibility as well as the costs of repairing this negative condition. Although the study has been carried out on a specific country under pre-defined settings, the rationale behind the proposals can easily be transposed to other scenarios because the scientific methods on which soil degradation has been defined and mapped are generally applicable, while the suggested legal values are currently applied to many regions on the planet.
\end{abstract}

\section{Introduction}

In Brazil, the environment is legally defined as "the set of conditions, laws, influences and interactions, of physical, chemical and biological nature, which shelters and governs life in all of its forms" (Federal Law no. 6938, published in 31 August 1981). Thus, to effectively protect the environment, laws need to follow scientific guidelines provided as one coherent multidisciplinary framework. There is an evident interaction between legal and technical concepts, the reason why social actors are called upon to have a holistic view on the environment.

The wide-ranging view on the links between science and norms presented in the previous paragraph is fully applicable to soil science and to the legal framework ruling the use of soil. In Brazil, there is no practicable management of agricultural, livestock or integrated croplivestock farming systems and their components without a proper consideration of laws and legislation, while there are many legal concepts transposed to laws that are appropriated from or resort to soil science principles for their practical application. In the complex interplay among soil uses and their legal constraints, the "polluter pays principle" (PPP) works as safeguard of soil conservation, because application of PPP by the authorities forces owners of rural or urban land towards the prevention, mitigation or recovery of environmental damages, namely through implementation of best management practices in their farms. The PPP underpins a major portion of regulation on pollution affecting land production and is related to environmental policy principles that require prevention and control of pollution.

Erosion is a major concern on the conservation of soil. It is a fact that erosion is a natural process related to the action of water, wind and ice on the ground surface. However, with the assistance of soil science it is possible to quantify a human-related acceleration of erosion and delineate the degraded areas derived therefrom. Among the methods offered to quantify hydric erosion rates, the most widely used is the

\footnotetext{
* Corresponding author at: Centro de Química de Vila Real, Universidade de Trás-os-Montes e Alto Douro, Ap 1013, 5001-801, Vila Real, Portugal.

E-mail address: fpacheco@utad.pt (F.A.L. Pacheco).
} 
Universal Soil Loss Equation (USLE) introduced by Wischmeier and Smith (1978) and revised by Renard et al. (1997). This algorithm has been used in numerous studies worldwide (e.g. Martín-Fernández and Martínez-Núñez, 2011; Valle Junior et al., 2010a), representing about one third of soil erosion assessments in Brazil (Barretto et al., 2009). Apart from conventional estimations of soil losses, the USLE has recently been used to investigate potential amplification of these losses resulting from the so-called environmental land use conflicts (Pacheco et al., 2014; Valle Junior et al., 2014a), which mean uses not conforming to land capability (the soil's natural use). However, these modeling exercises did not evolve to studies on the identification and delineation of human-related degraded areas that could be associated to the aforementioned conflicts. Using cross-tabulation tools of Geographic Information Systems (GIS), a number of studies compared images taken before and after the occurrence of specific land use changes (Abuelaish and Olmedo, 2016; Barati et al., 2015; Rysz and Janiszek, 2015), but these works were never focused on the association between changes in image characteristics and human-related soil degradation.

The development and maintenance (perpetuation) of degraded soils is highly adverse to terrestrial and freshwater ecosystems, the reason why human-related soil degradation has been classified as environmental damage (Article 3rd of Federal Law no. 6938/81). The perpetrator has a legal responsibility over the damage being forced to repair it (Number 3 of article 225th of Federal Constitution and number 1 of article 14th of Federal Law no. 6938/81).The main purpose of this paper is therefore to relate land use conflicts with human-related soil losses and environmental damages derived therefrom, while in complement the study explores the legal obligation of damage reparation by land owners in light of the polluter pays principle. The study area is located in the Uberaba River basin (Mina Gerais, Brazil), where accelerated soil losses have been documented and related to environmental land use conflicts.

\section{Materials and methods}

\subsection{Study area}

The Uberaba River and associated drainage network are located in the state of Minas Gerais (Brazil), in a sector of Triângulo Mineiro region, being limited by a catchment that covers an area of approximately $2419 \mathrm{~km}^{2}$. The hydrographic basin has been shaped within the following geographic coordinates: south latitude - 19 $30^{\prime} 37^{\prime \prime}$ -

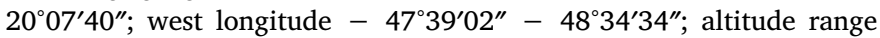
- $522 \mathrm{~m} \mathrm{-} 1031 \mathrm{~m}$ (Fig. 1). The region has distinctive weather regimes in winter and summer, being classified as Tropical by the international classification of Köppen (Cruz, 2003). While the winter season (running from October to April) is cold and dry the summer period (lasting from April to October) is hot and rainy. The mean annual temperature and precipitation are $23.2^{\circ} \mathrm{C}$ and $1584.2 \mathrm{~mm}$, respectively. Temperature ranges are large. In December and January maximum temperatures can reach $31.4^{\circ} \mathrm{C}$, whereas in May to July they can drop down to $13.6^{\circ} \mathrm{C}$. In the months of December and January precipitation approaches $1080 \mathrm{~mm}$. This is more than $2 / 3$ of all rainfall brought into the catchment in one year (Silva et al., 2007).

The geology of Uberaba River basin is characterized by PreCambrian quartzites and micaschists of Canastra Group, which have been overlaid by Mesozoic sandstones and basalts of São Bento Group and by Upper Cretaceous sandstones and conglomerates of Bauru Group that crop out across the entire watershed (Valle Junior et al., 2010b). The sedimentary sequences have been deposited in the N/NE portion of Parana sedimentary basin. The beds and margins of water courses are usually covered by Cenozoic alluvial and colluvial deposits, respectively. The weathering of sandstones and conglomerates produced average texture latosols (Fig. 2). The nomenclature of soil types exposed in this figure is in keeping with the Brazilian system of soil classification developed by the Empresa Brasileira de Pesquisa Agropecuária (Embrapa, 1999, 2006). In the Uberaba region, soils are particularly sensitive to erosion because the preparation of land for seeding occurring in fall overlaps the period of quite erosive rainfall events (Valle Junior et al., 2012, 2013). In 2014, land use in the Uberaba River watershed was dominated by agriculture-based activities (Fig. 3). Farmlands used for crop production (mostly sugar cane) were concentrated to the south while livestock pasturing dominated to the northern part of the basin. Besides agriculture, land was occupied by remnants of native vegetation, known as Cerrado, and by a dam lake located at the catchment outlet.

\subsection{Databases and software}

The assessment to human-related soil degradation was based on spatial cross-tabulations and subsequent comparisons between soil losses, tolerances to soil loss and environmental land use conflicts. To execute these analyses, a database composed of geographic elements and alphanumerical data (GIS database) had to be arranged and processed in proper software. The literature sources from which database elements have been downloaded, the rationale of using those elements for the recognition of soil losses, tolerances and conflicts, the identification of data owners and a mention to the website's URL (Uniform Resource Locator), are summarized in Table 1. The GIS database was operated by the IDRISI Selva software (Eastman, 2012; http://www.clarklabs.org). In the most recent years, GIS computer packages became widely used in a vast range of environmental applications (Pacheco and Landim, 2005; Pacheco and Van der Weijden, 2012a,b; Pacheco and Van der Weijden, 2014a,b; Pacheco et al., 2013, 2015a,b; Sanches Fernandes et al., 2012; Santos et al., 2014, 2015a,b).

\subsection{Soil losses}

The loss of soil by sheet and rill erosion was estimated by the USLE (Universal Soil Loss Equation). This empirical algorithm has been amply used in numerous studies (Martín-Fernández and MartínezNúñez, 2011; Wijitkosum, 2012), which followed the pioneering analysis of Wischmeier and Smith (1978) later revised in a paper by Renard et al. (1997). The applicability of the USLE to conditions beyond the area of its development (i.e. the agricultural USA east of the Rocky Mountains) has been considered in Brazil by Amorim et al. (2010). These authors compared experimental with USLE-based soil losses across various edaphoclimatic conditions and concluded that losses estimated by the USLE are systematically overestimated due to uncertainty in the assessment of various control factors $(K, C$ and $P$; see descriptions below). A linear regression could be set between experimental and estimated losses, written as "estimated loss" $=1.146 \times$ "measured loss" $+5.333 \mathrm{~kg} \mathrm{~m}^{-2}$ ), which represents an overestimation of approximately $15 \%$. For this reason, soil erosion data used in this study are viewed as "best estimates", not as definitive results.

The USLE produces estimates for the long-term mean annual soil loss $(A)$, as follows:

$A=R \times K \times L \times S \times C \times P$

where

$A-$ Soil loss per unit of area per unit of time $\left(\mathrm{t} \mathrm{ha}^{-1} \mathrm{yr}^{-1}\right)$;

$R$-Rainfall-runoff factor ( $\mathrm{MJ} \mathrm{mm} \mathrm{h}{ }^{-1} \mathrm{ha}^{-1} \mathrm{yr}^{-1}$ );

$\mathrm{K}$-Soil erodibility factor $\left(\mathrm{t} \cdot \mathrm{h} \cdot \mathrm{MJ}^{-1} \cdot \mathrm{mm}^{-1}\right)$;

$L$-Slope length factor (dimensionless);

$S$-Slope steepness factor (dimensionless);

$C$-Cover-management factor (dimensionless);

$P$-Support practice factor (dimensionless).

In the GIS platform (IDRISI Selva software), the map of soil losses 


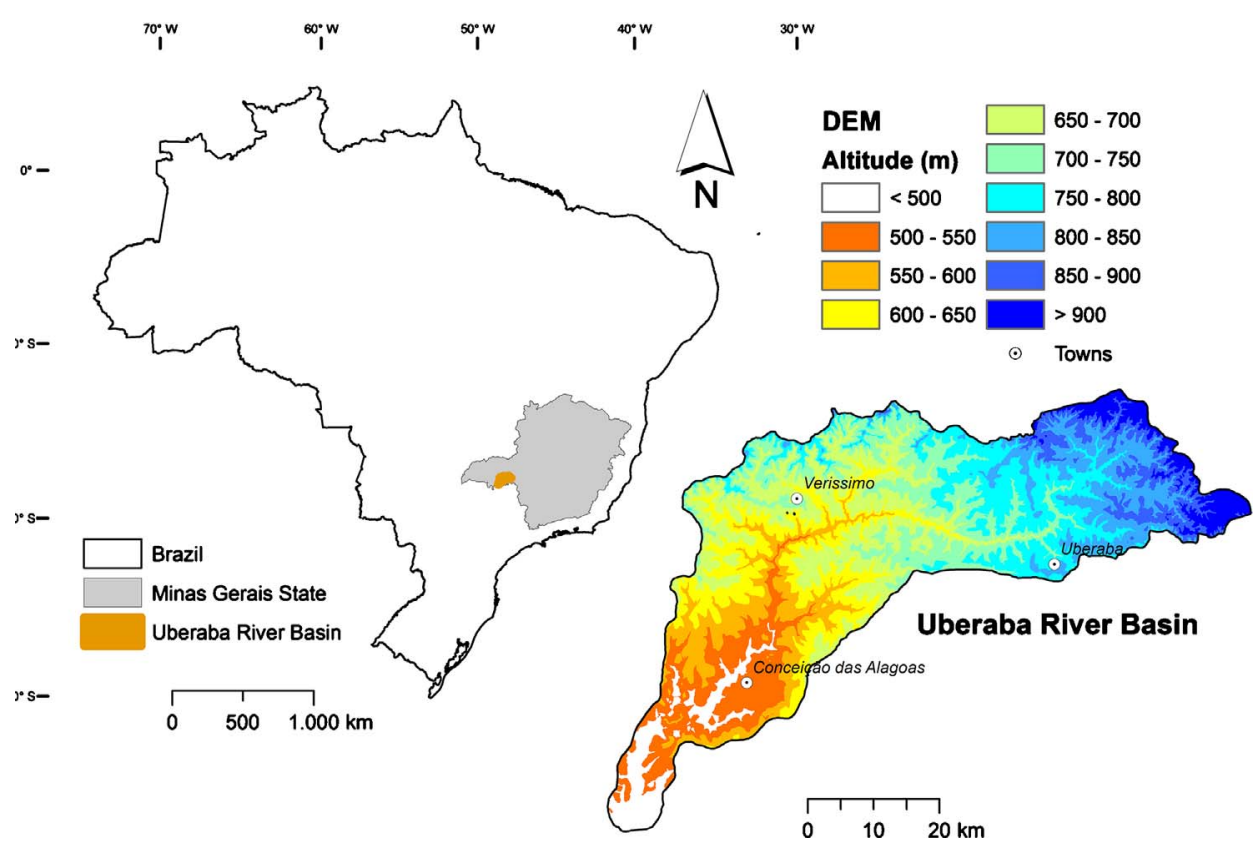

Fig. 1. - Location and topography of Uberaba River basin. Modified after Valera et al. (2016).

(A) was obtained from multiplication of maps prepared for the bearing variables $(R, K, L S$ and $C P)$, using the map algebra tool "Image Calculator". In all cases, maps were produced in raster format.

The map for the $R$ variable was based on a rainfall-runoff value generated from precipitation records obtained at the INMET (National Institute for Meteorology) station that is located nearby the studied basin (station no. 83577). The generation of one $R$ for the entire watershed followed a method described in Valle Junior et al. (2010a, 2012). In brief, the value of $R$ for one year was estimated by:

$R=\sum_{i=1}^{n}\left[I_{30} \sum_{j=1}^{p_{i}}\left(E c_{i, j}\right)\right]$

with
$E c_{i, j}=a+b \log \left(I_{i, j}\right)$

where $E c_{i, j}$ is the kinetic energy of precipitation estimated by the Wischmeier and Smith (1958) formula, evaluated within a segment $j$ of uniform intensity $I$ during an erosive rainfall event $i$, while $I_{30}$ is the maximum intensity of all isolated 30-min rainfall events identified within the entire precipitation record. In Eq. (2), the number of segments of uniform intensity in the event $i$ is $p_{i}$ and the number of erosive rainfall events in one year is $n$. Erosive events are characterized by total precipitation $\geq 10 \mathrm{~mm}$ and maximum intensity $\geq 24 \mathrm{~mm} \mathrm{~h}^{-1}$ in a period of $15 \mathrm{~min}$. Isolated events are those separated more than $6 \mathrm{~h}$ from the previous and the next event. In the International System of Units, the fitting parameters $a$ and $b$ are given by: $a=0.119$; $b=0.0873$ (Foster et al., 1981).

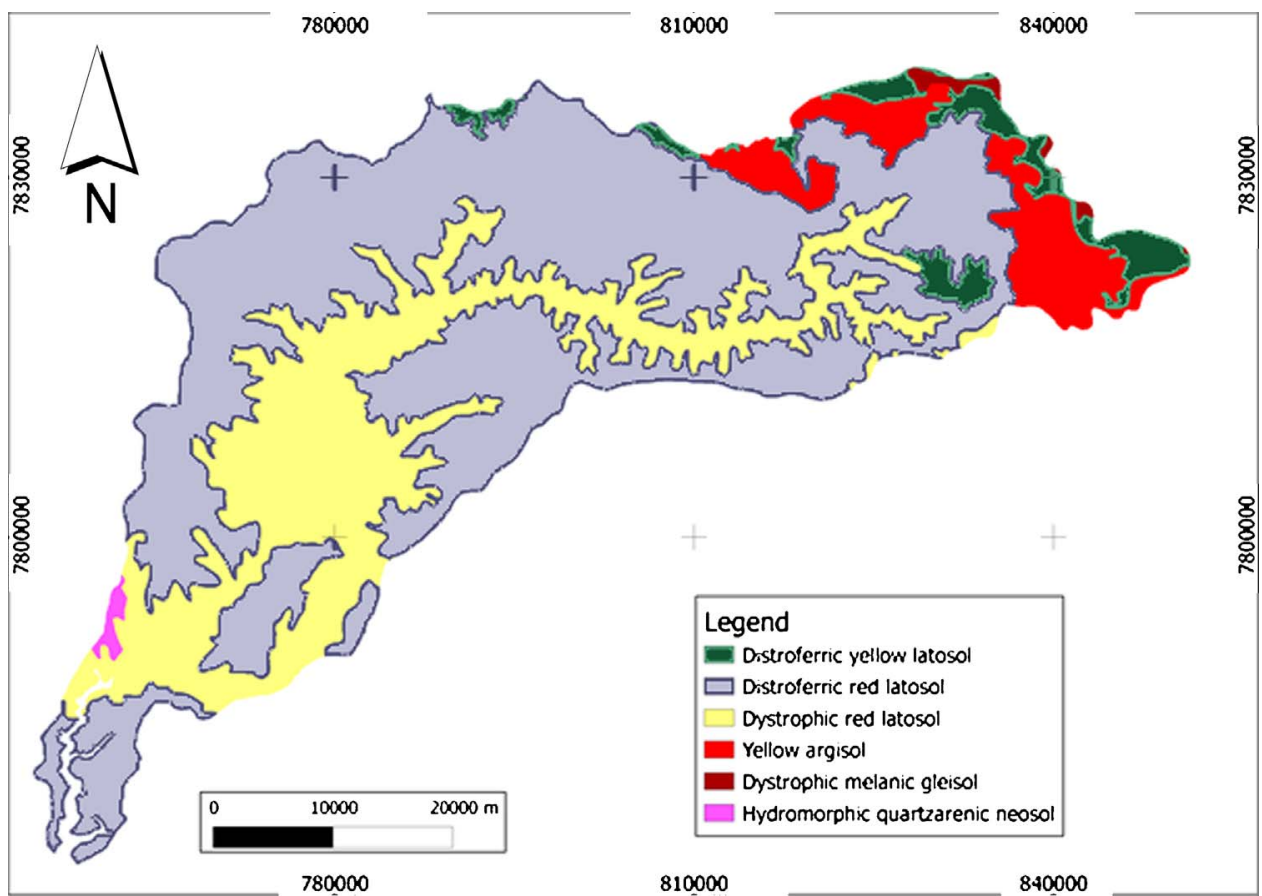

Fig. 2. - Soil map of Uberaba River basin. Modified after Cruz (2003). 


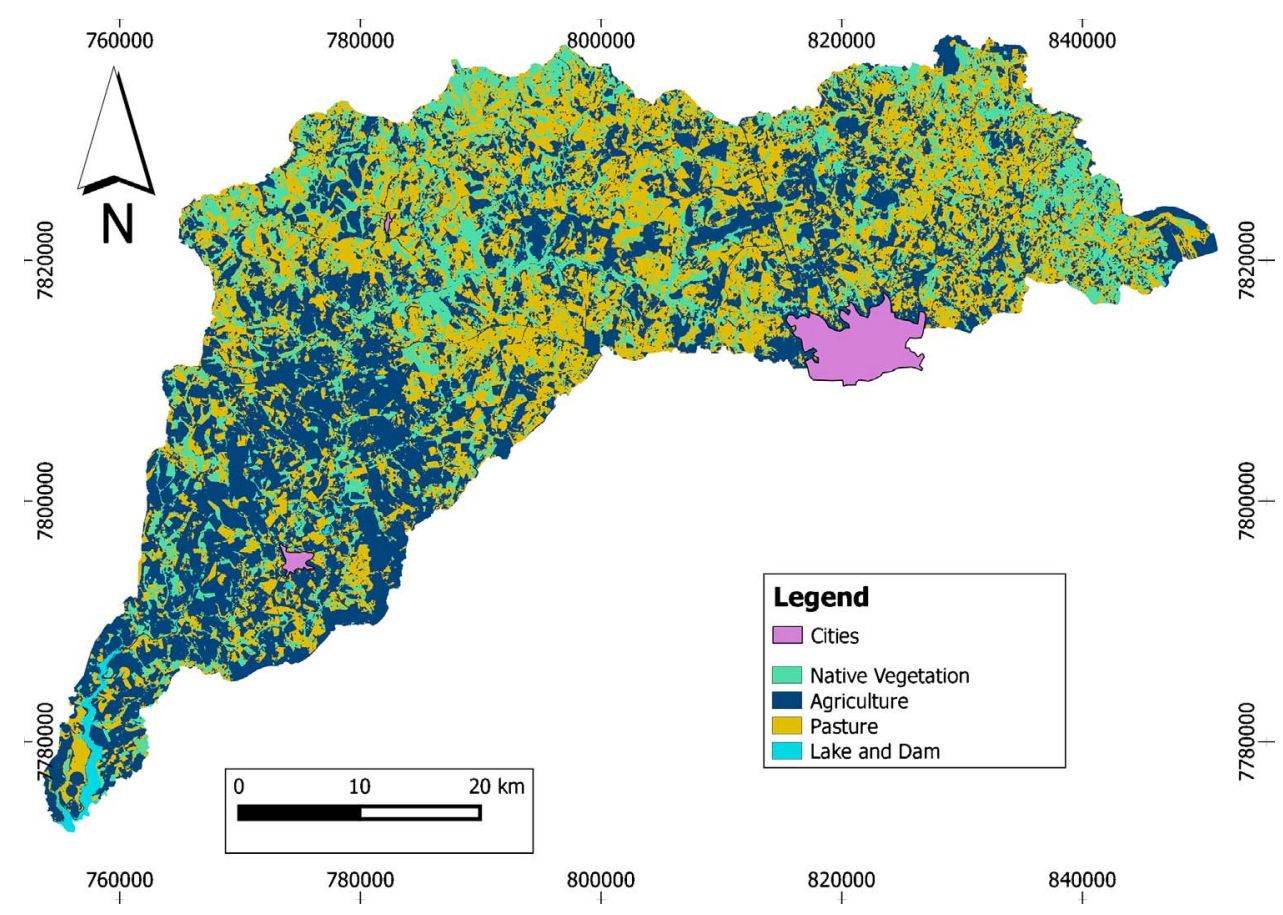

Fig. 3. - Land use map of Uberaba River basin, in 2014. The land uses were interpreted from LANDSAT 8 sensor OLI-TIRS images.

For the mapping of $K$ within the Uberaba River watershed, the IDRISI Selva software was populated with a soil map (Fig. 2) for the identification and spatial delineation of soil types and sub-types, coupled with information on chemical and physical properties of a representative number of soil samples distributed within the catchment for the estimation of soil erodibility factors, compiled from Embrapa (1982). The method for evaluating a mean $K$ for each soil type and subtype has been presented in Valle Junior et al. (2010a). The method is particularly well described in Demarchi and Zimback (2014), where it can be consulted for details. In short, the values of $K$ were evaluated by an empirical relationship based on multiple regression analysis (Denardin, 1990), which used field measurements of soil erodibility as dependent variable and physic-chemical parameters of soil samples as independent variables:

$K=c_{1} M+c_{2} P+c_{3} D M P+c_{4} O M$

where $M$ is the quotient of fine sand + silt over the fraction fine sand + silt + coarse sand, $P$ is a texture-based permeability rating varying from 6 (clayey to clay-loam textures) to 1 (sandy textures), DMP is the weighted mean diameter of $\leq 2 \mathrm{~mm}$ soil particles, $O M$ is the product of organic matter and the percentage of $\geq 0.1 \mathrm{~mm}$ sand particles, and $c_{1}$ to $c_{4}$ are fitting parameters $\left(c_{1}=0.00000748, c_{2}=0.00448059\right.$, $\left.c_{3}=0.06311750, c_{4}=0.01039567\right)$. The modeling exercise of Denardin (1990) produced very high coefficient of determination $\left(R^{2}=0.98\right.$ and very low standard error for the $K$ estimates $\left(0.006 \mathrm{th} \mathrm{MJ}^{-1} \mathrm{~mm}^{-1}\right)$. The soil samples on which the regression analysis has been performed were collected in Brazil and the United States. The mean $K$ values estimated for the soil types and sub-types of Uberaba River basin are depicted in Table 2.

The slope length $(L)$ and slope steepness $(S)$ factors were included in the USLE equation to measure the combined erosive effects of runoff volume and velocity, respectively, the reason why are frequently determined as lumped parameter LS. According to Bertoni and Lombardi Neto (1999), a power relationship exists between $L S$ and the bearing variables ( $L$ and $S$ ):

Table 1

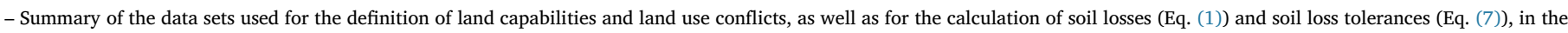
Uberaba River basin. The table columns include references to data types and their uses in the analysis, as well as to data ownership and internet availability.

\begin{tabular}{|c|c|c|}
\hline Database & Purpose & Owner institution and URL of internet website \\
\hline Precipitation records & $\begin{array}{l}\text { Calculation of a rainfall-runoff factor for the entire basin (parameter } \\
R \text { ) }\end{array}$ & $\begin{array}{l}\text { INMET - Instituto Nacional de Meteorologia. http:// } \\
\text { www.inmet.gov.br/ }\end{array}$ \\
\hline $\begin{array}{l}\text { Soil map from Minas Gerais State and } \\
\text { associated physical, chemical and } \\
\text { structural data }\end{array}$ & $\begin{array}{l}\text { Calculation of soil erodibility factors (parameter } K \text { ) and soil tolerances } \\
\text { (parameter } T \text { ) }\end{array}$ & $\begin{array}{l}\text { FEAM - Fundação Estadual do Meio Ambiente. http:// } \\
\text { www.dps.ufv.br/. } \\
\text { EMBRAPA - Empresa Brasileira de Pesquisa } \\
\text { Agropecuária. Ministério da Agricultura, Pecuária e } \\
\text { Abastecimento. https://www.embrapa.br/ } \\
\text { EPAMIG - Empresa de Pesquisa Agropecuária de Minas } \\
\text { Gerais. http://www.epamig.br/ }\end{array}$ \\
\hline Digital Elevation Model & $\begin{array}{l}\text { Calculation of terrain slopes }(S l) \text { and the slope steepness factor } \\
\text { (parameter } S) \text {. Preparation of drainage network and sub-basin } \\
\text { shapefiles for the calculation of drainage densities }\left(D_{d}\right) \text { and the slope } \\
\text { length factor (parameter } L) \text {. Calculation of ruggedness numbers } \\
\left(R N=S l \times D_{d}\right) \text { and definition of land capabilities }\end{array}$ & $\begin{array}{l}\text { USGS - United States Geological Survey. http:// } \\
\text { earthexplorer.usgs.gov/ }\end{array}$ \\
\hline $\begin{array}{l}\text { Orbital images LANDSAT } 8 \text { sensor OLI- } \\
\text { TIRS, sensor orbit/point } 220 / 074 \text {, } \\
\text { obtained in June } 2,2014\end{array}$ & $\begin{array}{l}\text { Preparation of a land use map of Uberaba River basin for the definition } \\
\text { of cover management and support practice factors (parameter } C P \text { ), as } \\
\text { well as land use classes/conflicts }\end{array}$ & $\begin{array}{l}\text { USGS - United States Geological Survey. http:// } \\
\text { earthexplorer.usgs.gov/ }\end{array}$ \\
\hline
\end{tabular}


Table 2

- Mean soil erodibility factors $(K)$ and soil tolerances $(T)$ of Uberaba River soil types and sub-types (Fig. 2), estimated by Eq. (3) (Section 2.3) and Eq. (7) (Section 2.5), respectively, using the proper soil data compiled from Embrapa (1982).

\begin{tabular}{llr}
\hline Soil type or sub-type & $K$ & $T$ \\
\hline Distroferric yellow latosol & 0.020 & 25.87 \\
Distroferric red latosol & 0.022 & 22.98 \\
Dystrophic red latosol & 0.017 & 14.21 \\
Yellow argisol & 0.028 & 17.78 \\
Hydromorphic quartzarenic neosol & 0.027 & 2.14 \\
\hline
\end{tabular}

$L S=\left(\frac{L}{L_{p}}\right)^{m} \times\left(\frac{S}{S_{p}}\right)^{n}$

where $m=0.63$ and $p=1.18$ are fitting parameters while quotients $L /$ $L \mathrm{p}$ and $S / S_{\mathrm{p}}$ calibrate $L S$ estimates of natural hillsides in regard to experimental surfaces of standard length $L_{p}=25 \mathrm{~m}$ and slope $S_{p}=9 \%$. The evaluation of $L$ and $S$ within a catchment requires prior application of terrain modeling tools of IDRISI Selva software to identify small subcatchments of uniform morphometric parameters and then to calculate the area $\left(A_{i}\right)$, mean ground slope $\left(s_{i}\right)$ and total length of water channels $\left(l_{i}\right)$ for each sub-catchment $i$. Subsequently,

$L_{i}=\frac{A_{i}}{4 l_{i}}$

$S_{i}=s_{i}$

Derivation of Eq. (6a) relies on the so-called equivalent rectangle method (Villela and Mattos, 1975).

The $C$ factor evaluates the protective shield against hydric erosion, of forest canopy as well as of plant and animal residues in direct contact with the Earth's floor. The $P$ factor considers the role of conservation practices in the reduction of soil particles export in runoff, namely of terrace construction or seeding/plantation along topographic contours (Wischmeier and Smith, 1978). Although related to distinctive soil erosion control variables, it is sometimes difficult to discriminate the roles of $C$ and $P$ in a particular setting, because land occupations are usually associated to specific conservation practices. For that reason, many authors considered the possibility of using a lumped $C P$ parameter to account for the combined effect of vegetation cover and support practices. Stein et al. (1987) were among the authors affirming that $C$ and $P$ factors are so strongly related to each other that they cannot be analyzed individually for the estimation of soil loss by hydric erosion (Dalmas et al., 2015). In the sequel, these authors proposed specific values of $C P$ for a number of land uses, from which we compiled the values depicted in Table 3 that were used in this study.

\subsection{Environmental land use conflicts}

The natural use of a land is the one conforming to soil capability set up according to its physical, chemical and structural characteristics. However, actual uses frequently ignore this condition and deviate from capability developing environmental land use conflicts. An exhaustive assessment of land capability requires the accounting of numerous parameters (see for example Agroconsultores and Coba, 1991), which is

Table 3

- Lumped $C P$ (cover-management factor coupled with support practice factor) values for the various land uses of Uberaba River basin (Fig. 3), as proposed by Stein et al. (1987).

\begin{tabular}{ll}
\hline Land Use & $C P$ value (dimensionless) \\
\hline Water bodies (Uberaba dam lake) & 0.00000 \\
Native vegetation & 0.00522 \\
Pasture & 0.05500 \\
Agriculture & 0.16370 \\
Bare land (cities) & 1.00000 \\
\hline
\end{tabular}

costly and time consuming. Less expensive routes to accomplish this task resort to expeditious algorithms based on morphometric analysis. A common approach equates land capability to the ruggedness number $(R N$; Strahler, 1952), which is the product of topographic slope $(S l)$ and drainage density $\left(D_{\mathrm{d}}\right.$; Horton, 1945). There is a rationale following the association between $R N$ and land capability, because sectors of a watershed with a low $R N$ are generally adapted to cropping agriculture as they correspond to smoothly dissected undulations, while sectors with a high $R N$ are better tailored to forestry activities as they typically match the most dismembered and inclined landscapes. Finally, the parts of a catchment with intermediate $R N$ are proper for livestock pasturing or for a mosaic of natural pastures and forests. The procedure to calculate the $R N$ has been detailed in various studies (Pacheco and Sanches Fernandes, 2016; Rocha and Kurtz, 2001; Valle Junior et al., 2013, 2014b, 2015). According to that protocol, the boundaries of each $R N$ class are set up in four consecutive steps: (a) a number of sub-basins is identified and delineated across the watershed in appreciation; $(b)$ the mean $S l$ and $D_{\mathrm{d}}$ of each sub-basin are estimated, from which the corresponding $R N$ is obtained; (c) the $R N$ amplitude (maxRN - minRN) is estimated, where maxRN is the highest and minRN the lowest $R N$, and then divided by a pre-defined number of land capability classes $(n)$, for example the four classes used in this study $(n=4)$ : 1-Agriculture, 2-Pastures for livestock production, 3-Pastures for livestock production/Forestry and 4-Forestry; $(d)$ the sub-basins are assigned to the classes, based on their individual $R N$ scores, from which a land capability map is prepared.

Having estimated the capability, conflicts are quantified as follows: a) land capabilities and actual uses are ranked in ascending order of their resemblance with agriculture, and given the ranks 1 (agriculture), 2 (livestock production), 3 (mixed livestock production and forestry) and 4 (forestry); $b$ ) the conflict is equated to the difference between the codes of capability $(1 \leq N \leq 4)$ and actual land use $(1 \leq A \leq 4)$. According to this method, $i$ ) the no conflict areas are represented by regions where $N-A \leq 0$, with the negative values representing areas with potential for a sustainable expansion of agriculture or livestock pasturing; ii) areas where the difference between capability and actual use is equal to 1,2 or 3 are classified as Class $1(N-A=1)$, Class $2(N$ $-A=2)$ or Class $3(N-A=3)$ conflict areas, respectively.

\subsection{Soil losses in conflict areas and tolerances to soil loss}

Following the calculation of soil losses and delineation of land use conflicts (Sections 2.3 and 2.4), a step forward was attained with a cross-tabulation of losses within conflict regions. The specific aim was to calculate the area occupied by a class of soil loss $i$ within a region of conflict $j$, so the role of human-related hydric erosion could be objectively stated. The task was executed using the CROSSTAB tool of IDRISI Selva software. To fully attain the purpose of evaluating a potential damage to soil and general environment caused by human action, the soil losses in conflict and non-conflict areas were compared with soil tolerances to hydric erosion estimated by the method of Oliveira (2004). According to this method, the tolerance of a soil to hydric erosion $(T)$ is estimated by:

$T=h \times r_{a} \times m \times p \times 1000^{-1}$

where $h(\mathrm{~mm})$ is the soil's effective depth; parameter $0.4 \leq r_{\mathrm{a}} \leq 1.0$ is a factor describing the combined effects of increasing clay content and decreasing textural relation among $\mathrm{A}$ and $\mathrm{B}$ horizons on soil tolerances, for clay contents in the range $>20-<40 \%$ and textural relations in the range $>2-<1.5$; parameters $0.5 \leq m \leq 1.15$ and $0.7 \leq p \leq 1.0$ are factors describing the effects of increasing organic matter and permeability of top $20 \mathrm{~cm}$ layer on soil tolerances, respectively, for $1 \leq$ organic matter $\leq 2 \%$ and $5.1 \leq$ permeability $\leq 63.5 \mathrm{~mm} \mathrm{~h}^{-1}$. The comparison of losses ( $A$; Eq. (1)) and tolerances (T; Eq. (7)) was based on the definition of three tolerance classes: 1-tolerable, with soil losses clearly below the tolerance limit $(A<<T)$; 2-null or incipient, 
with soil losses comparable to tolerances $(A \approx T)$; and 3-intolerable, with soil losses visibly above the tolerance threshold $(A>>T)$.

\section{Results}

The calculus of soil losses and tolerances in the Uberaba River basin has been presented in a previous study conducted by Valle Junior et al. (2010a). The results are reproduced here for the sake of supporting a forthcoming discussion on environmental damage and consequent application of the polluter pays principle, because there are strong evidences related to human-related acceleration of soil erosion in this basin. The period for analysis of $R$ comprised the civil years of 1999-2004. Within this period, the number of isolated rainfall events was 703 but only 311 were considered erosive. For the erosive events, the mean rainfall-runoff factor was $R=7846.54 \pm 2.124 .16$ $\mathrm{MJ} \mathrm{mm} \mathrm{h}{ }^{-1} \mathrm{ha}^{-1} \mathrm{yr}^{-1}$, which is considered high according to Silva et al. (2003). Using the GIS software (IDRISI Selva), a raster file was produced with a constant cell value equal to $R$ for the entire basin. A raster file was also prepared for the $K$ parameter, but this time cell values were not constant across the watershed. Now, the $K$ values in Table 2 were first assigned to the various soil types portrayed in Fig. 2 (with exception of dystrophic melanic gleisol because data were lacking for this soil type) and then the raster file was produced according to these $K$ values. A third raster file was arranged for the $L S$ parameter, based on $L$ and $S$ values (Eqs. (6a),(6b)) estimated from sub-basin/ drainage network and terrain slope maps (Fig. 4a,b), respectively. Approximately $3 / 4$ of all estimated slope lengths are within the range $200-400 \mathrm{~m}$ while $2 / 3$ of all terrain slopes vary between 0 and $5 \%$. So, although the $L S$ parameter influences soil erosion in the Uberaba River basin, it cannot be considered the most important factor. As with parameter $K$, the fourth raster file was produced by first assigning $C P$ values from Table 3 to the various land uses illustrated in Fig. 3, and then by converting this vector map into a pixel map based on those $C P$

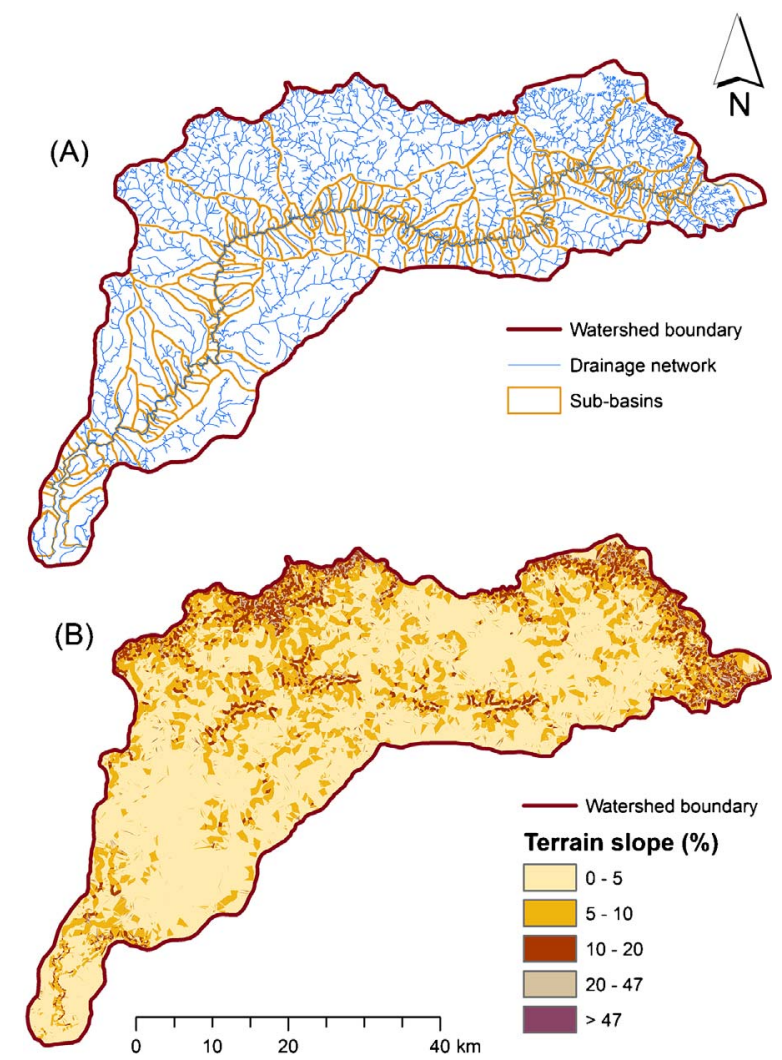

Fig. 4. - Drainage network, sub-basins (panel $a$ ) and slope classes (panel $b$ ) in Uberaba River basin. values. The dominant land uses (pastures and crop agriculture) are prone to soil erosion, being characterized by $C P$ values of 0.055 and 0.1637, respectively. The final soil loss map, obtained from multiplication of previously prepared $R, K, L S$ and $C P$ maps (Eq. (1)), on a cell by cell basis, is shown in Fig. 5 . The range of estimated soil losses is wide, being concentrated in the classes $0-10$ (41.1\% of Uberaba River basin) and $15-50(32.9 \%) \mathrm{tha}^{-1} \mathrm{y}^{-1}$ and showing a significant portion of values above $50 \mathrm{t} \mathrm{ha}^{-1} \mathrm{y}^{-1}$ (17.5\% of the area). The estimated mean soil loss in the basin is $28.9 \mathrm{tha}^{-1} \mathrm{y}^{-1}$, which means moderate (Table 4). When this global mean is discriminated among conflict and non conflict areas one sees that mean soil losses in non conflict areas are estimated as $24.5 \mathrm{tha}^{-1} \mathrm{y}^{-1}$ (moderate) and in conflict areas as $55.0 \mathrm{tha}^{-1} \mathrm{y}^{-1}$ (high).

The $R N$-based land capabilities are illustrated in Fig. 6. This figure resulted from a combination of a drainage density map, drawn from drainage network and sub-basin cartograms (Fig. 4a), and a terrain slope map (Fig. 4b). According to Fig. 6, approximately half (48.7\%) of the basin is capable of being used for crop agriculture, while the remainder is suited for livestock pasturing (37.6\%), an occupation by a mosaic of pastures and forest spots (12.3\%) and extensive forestry (1.4\%). However, uses in 2014 were not following the capabilities in a large portion of the basin, because the area occupied by land use conflicts (Fig. 7) reached $539.2 \mathrm{~km}^{2}$ (22.3\% of the basin), mostly of Class $1\left(418.2 \mathrm{~km}^{2} ; 17.3 \%\right)$ and Class $2\left(110.9 \mathrm{~km}^{2} ; 4.6 \%\right)$ as depicted in Table 4. A thorough inspection of Table 4 reveals how soil losses are extremely sensitive to the conflicts. The areas occupied by null to moderate soil losses represent $1660.9 \mathrm{~km}^{2}$ of non-conflict areas and $334.7 \mathrm{~km}^{2}$ of conflict areas, which means the smaller losses are 5 times more represented in non-conflict than in conflict areas. However, when the areas occupied by high to very high losses are compared among non-conflict and conflict regions, one sees that non-conflict areas cover $219 \mathrm{~km}^{2}$ and conflict areas cover $204.9 \mathrm{~km}^{2}$, which means they are equally important at these larger losses. The close inspection of Table 4 also shows a percent increase of areas occupied by high-very high losses as one considers the non-conflict (11.6\%), conflict Class 1 (35.5\%), conflict Class $2(44.7 \%)$ or conflict Class $3(65.3 \%)$ areas. The occupation by soil tolerance classes is displayed at the bottom of Table 4 . The areas covered by intolerable soil losses represent $39.7 \%$ of the basin $\left(960.3 \mathrm{~km}^{2}\right)$, which is preoccupying. Even more worrying is the percent increase of such areas as one moves from non-conflict areas (32.0\%) to conflict Class 1 (64.3\%), conflict Class 2 (73.9\%), or conflict Class $3(82.1 \%)$ areas.

\section{Discussion}

\subsection{Human-related soil degradation and potential environmental damage}

Accelerated soil erosion has a long-standing association to the practice of agriculture (Lepsch, 2002), with numerous examples of soil degradation and desertification influenced by human activities being recently reported in the scientific literature (Golmohammadi, 2013; Silva et al., 2013; Wijitkosum, 2016; among others). In the present study, human-related soil degradation is being investigated from a novel perspective, which is the land use conflict, and is being linked to potential environmental damage.

The occupation of Uberaba River basin by conflict areas has grown considerably in the last decade. In 2008, the regions affected by conflicts of classes 1,2 and 3 covered $363.80,43.92$ and $5.41 \mathrm{~km}^{2}$, respectively (Valle Junior et al., 2013). Six years later (in 2014), as reported in the present study (Table 4), the conflict areas have raised by some 54.4 (class 1), 67.0 (class 2) and 4.7 (class 3) $\mathrm{km}^{2}$. The increase of conflict areas might have expanded the regions affected by intolerable soil losses, as they were reported to cover $905.2 \mathrm{~km}^{2}$ in 2008 (Valle Junior el. al., 2010a) and more $55.1 \mathrm{~km}^{2}$ in 2014 (Table 4). The increase of soil losses beyond the tolerance threshold triggers soil degradation and ultimately leads to desertification with consequences 


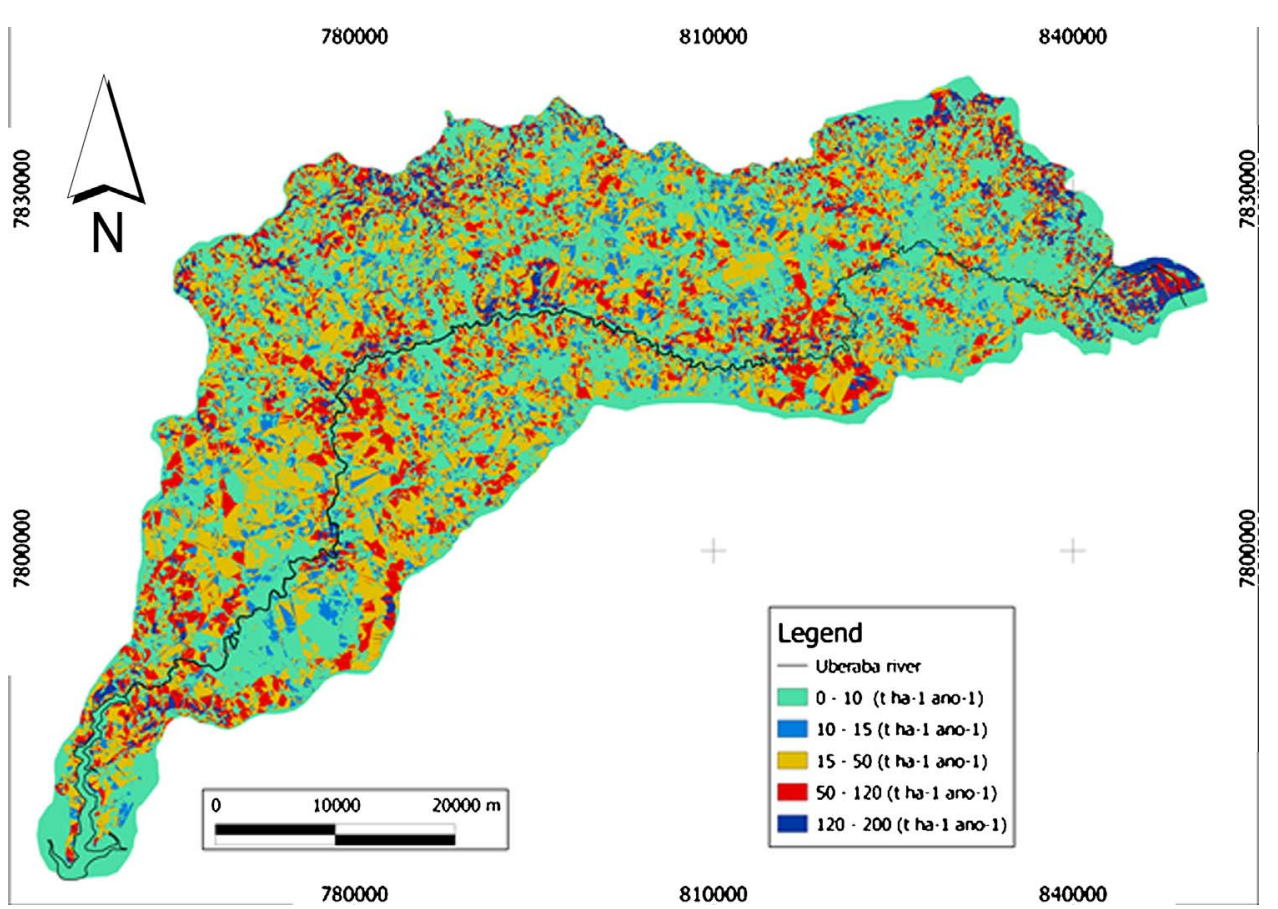

Fig. 5. - Soil losses in the Uberaba River basin, estimated by the USLE (Eq. (1)), as described in Section 2.3. Modified after Valle Junior et al. (2010a).

Table 4

- Spatial distribution of soil loss and tolerance classes within conflict and non-conflict areas. The soil loss classes are expressed in units of $\mathrm{tha}^{-1} \mathrm{y}^{-1}$. The occupations are expressed as square kilometers $\left(\mathrm{km}^{2}\right)$. The conflicts refer to the year of 2014 in keeping with the spatial distribution of uses portrayed in .

\begin{tabular}{|c|c|c|c|c|c|c|}
\hline \multirow{2}{*}{$\begin{array}{l}\text { Soil loss and } \\
\text { tolerance classes }\end{array}$} & \multicolumn{4}{|l|}{ Conflicts } & \multirow[t]{2}{*}{ Sum } & \multirow[t]{2}{*}{ Percent } \\
\hline & No conflict & Class 1 & Class 2 & Class 3 & & \\
\hline \multicolumn{7}{|c|}{ Occupation by soil loss classes } \\
\hline $\begin{array}{l}0-10 \text { (null to very } \\
\text { low) }\end{array}$ & 912.9 & 65.0 & 15.6 & 1.3 & 994.8 & 41.1 \\
\hline 10-15 (low) & 170.9 & 29.4 & 4.8 & 0.3 & 205.3 & 8.5 \\
\hline 15-50 (moderate) & 577.2 & 175.5 & 40.9 & 1.9 & 795.5 & 32.9 \\
\hline 50-120 (high) & 191.6 & 113.0 & 29.5 & 4.0 & 338.1 & 14.0 \\
\hline 120-200 (very high) & 27.4 & 35.3 & 20.0 & 2.6 & 85.4 & 3.5 \\
\hline \multicolumn{7}{|c|}{ Occupation by soil tolerance classes } \\
\hline $\begin{array}{l}\text { Below the tolerance } \\
\text { limit }\end{array}$ & 1142.9 & 129.3 & 19.9 & 0.9 & 1292.9 & 53.5 \\
\hline $\begin{array}{l}\text { Above the tolerance } \\
\text { limit }\end{array}$ & 601.3 & 268.8 & 81.9 & 8.3 & 960.3 & 39.7 \\
\hline Null or Incipient & 135.6 & 20.1 & 9.1 & 1.0 & 165.8 & 6.9 \\
\hline Sum & 1879.8 & 418.2 & 110.9 & 10.1 & 2419.0 & 100.0 \\
\hline Percent & 77.7 & 17.3 & 4.6 & 0.4 & 100.0 & \\
\hline
\end{tabular}

for crop productivity and environmental security and hence to regional or even global economy and social welfare. This is being recurrently documented in the scientific literature (Bradley and Grainger, 2004; De la Rosa et al., 2000; D’Odorico et al., 2013; Lal and Moldenhauer, 1987; Leighton, 2006; Liu et al., 2011; Pimentel et al., 1995; Zhao et al., 2006). Because the progress of soil degradation seems to correlate well with conflict area expansion (this study), it would be appropriate to classify soil degradation or desertification caused by a deviation of actual land uses from land capability as human-related environmental damage, because the consequences of degradation fit well the legal definition of environmental damage, as detailed below.

Soil losses are determined by a number of factors (Eq. (1)). A factor inherently related to the soil is factor $K$ (erodibility), which depends, among other variables, on the organic matter content (Eq. (4)). A recent study carried out in the Uberaba River basin (Valera et al., 2016) have shown that conflict area densification have drastically reduced the percentage of organic matter in the top soil $\left(5 \mathrm{~kg} / \mathrm{m}^{3}\right.$ per $10 \%$ increases in conflict area density). On the other hand, various independent studies have related the intensification of soil erosion to decreases in organic matter (Borrelli et al., 2016; Conforti et al., 2013; and references therein). It is therefore defendable a sequence of events initiated with deviations of actual from natural soil uses, followed by development and densification of land use conflicts, terminated with intensification of erosion, desertification and environmental damage. It is worth noting that this environmental damage is not restricted to a potential disruption of soil services such as decline in crop productivity caused by loss of fertility, because conflicts and associated decreases in organic matter may activate a propagation of impacts involving the amplification of nutrient exports towards the water masses eventually succeeded by lake eutrophication and decline in aquatic biodiversity (Liu et al., 2011; Pacheco and Sanches Fernandes, 2016; Valle Junior et al., 2014b, 2015). It is also worth recalling that soil losses exceeding the tolerance limit under natural erosion conditions tend to occur primarily along steep hillsides or water divides (Valle Junior et al., 2010b). This is not the picture shown in Fig. 8, where intolerable losses are widespread across the basin covering a total area of $960.3 \mathrm{~km}^{2}$. For that reason, the areas requiring legal protection against desertification are not only the already protected sectors of slope $\geq 45 \%$ included in the so-called Permanent Preservation Areas and Legal Reserve (New Forest Code; - Federal Law no. 12651/2012), but all the areas affected by intolerable soil loss, which cover a vast spectrum of slopes and soil types.

Besides any legal protection, the recovery of soils and their services can be attained through implementation of conservation practices. Zero tillage conservation agriculture is among the most efficient approaches to accomplish this objective. This approach comprises a set of conservation measures, like cover cropping, permanent soil cover with crop residues, crop rotations, among others, and has expanded in Brazil in the last two decades (Freitas and Landers, 2014).

\subsection{Legal framework for applying the polluter pays principle to soil conservation}

A framework model for applying the polluter pays principle to soil conservation is portrayed in Fig. 9. The polluter pays principle was 


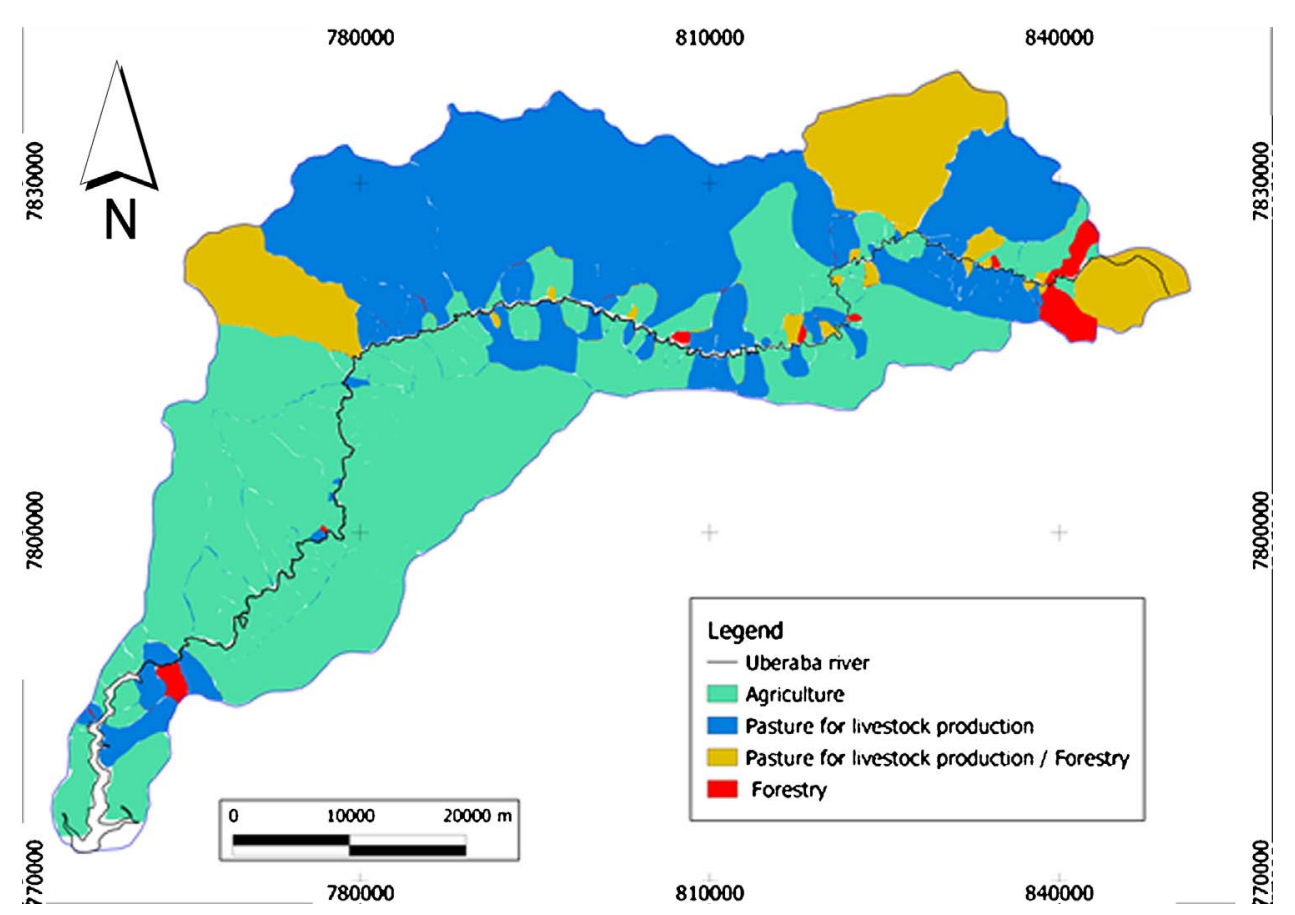

Fig. 6. - Land capabilities in the Uberaba River basin, set up by ruggedness numbers (see details in Section 2.4). Modified after Valle Junior et al. (2010a).

introduced in Brazil in 1992 as Principle 16 of Rio Declaration on Environment and Development, which states: "National authorities should endeavour to promote the internalization of environmental costs and the use of economic instruments, taking into account the approach that the polluter should, in principle, bear the cost of pollution, with due regard to the public interest and without distorting international trade and investment". On the other hand, the Doctrine of Right provides the following concept on the polluter pays principle: "The use of natural resources, across the production cycle of goods and services, entails the generation of negative externalities, notably in terms of pollution and environmental degradation. In this context, the polluter pays principle internalizes at productive practices (ultimately at the price of goods and services) the associated ecological costs, avoiding the indiscriminate support of that burden by the whole society" (Sarlet and Fensterseifer, 2014). Being in a process of degradation with potential development of environmental damage, the regions affected by intolerable soil losses could therefore be protected under the polluter pays principle and the consequent imposition of environmental responsibility to land owners.

As regards environmental damage, precaution or prevention has priority over remediation. The principle of precaution is applicable when there is uncertainty or technical doubt on whether an action will cause environmental damage or not; the principle of prevention imposes a restriction to the action when it is certain that the action will produce an environmental damage. As demonstrated in the

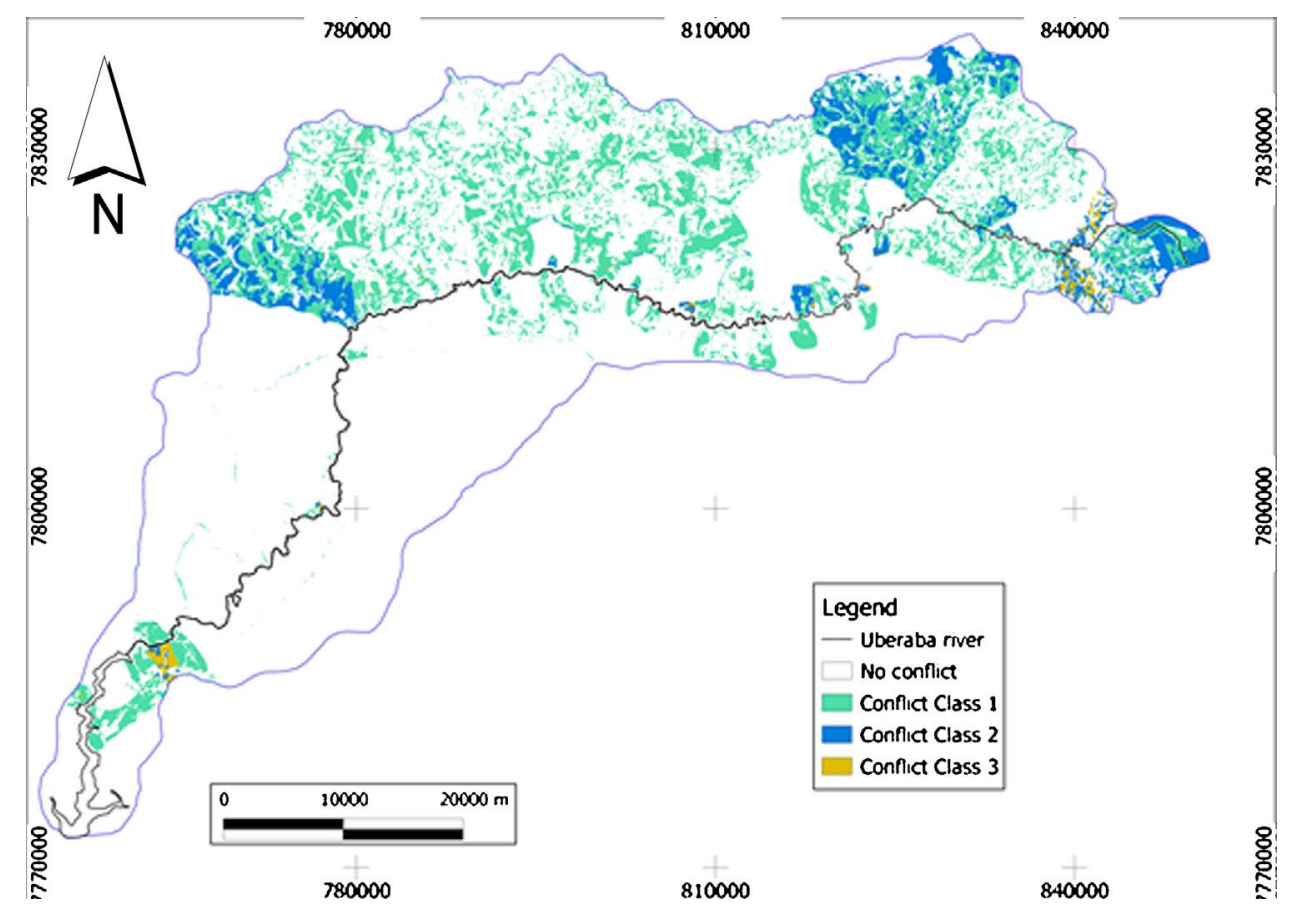

Fig. 7. - Land use conflicts in the Uberaba River basin, in 2014, defined as deviation between land capability and actual land use as detailed in Section 2.4 . 


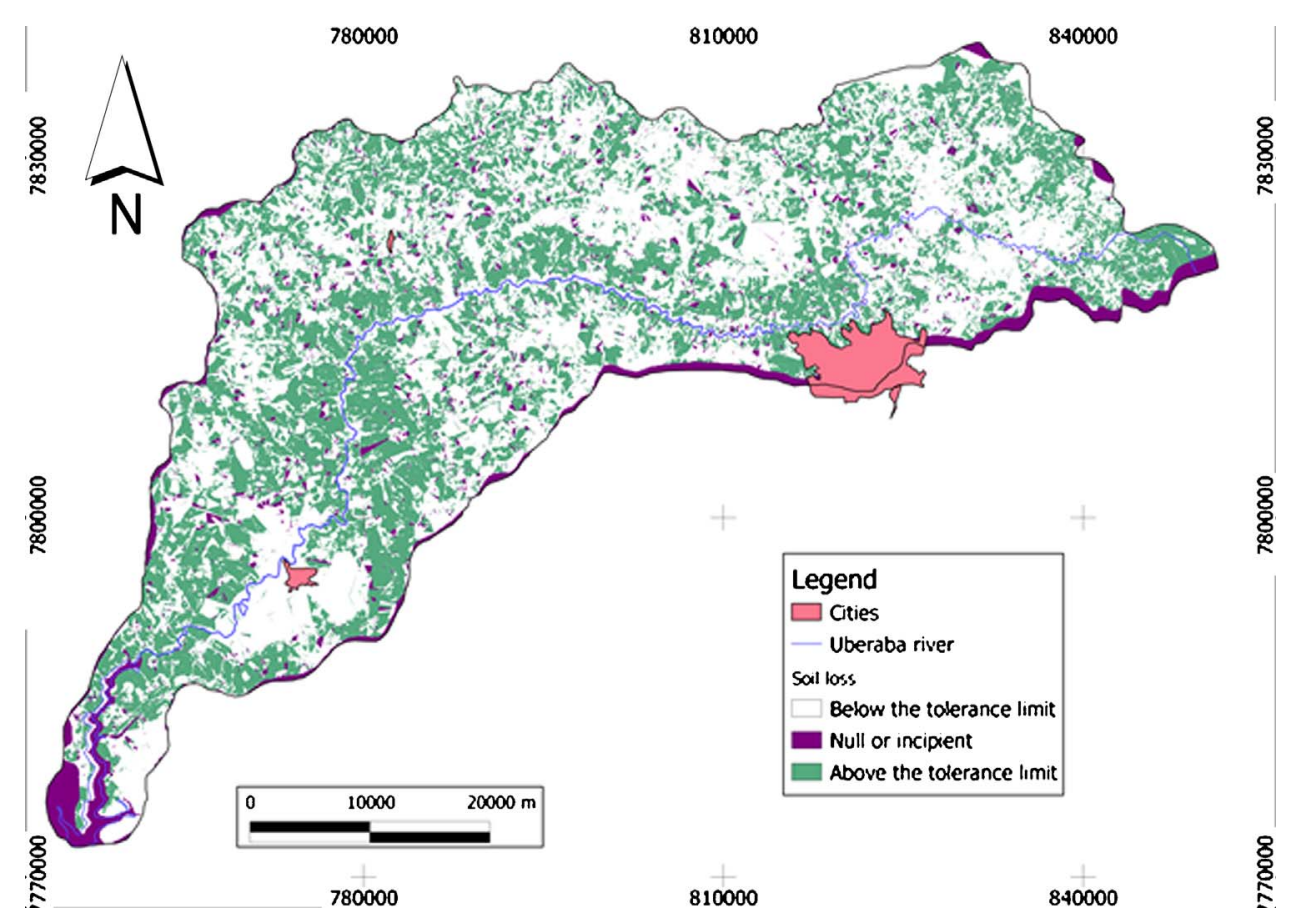

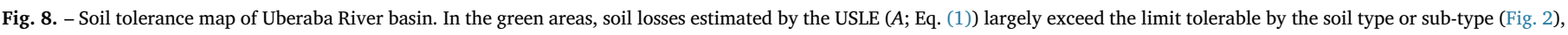

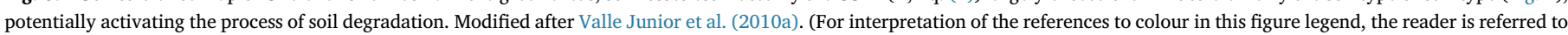
the web version of this article.).

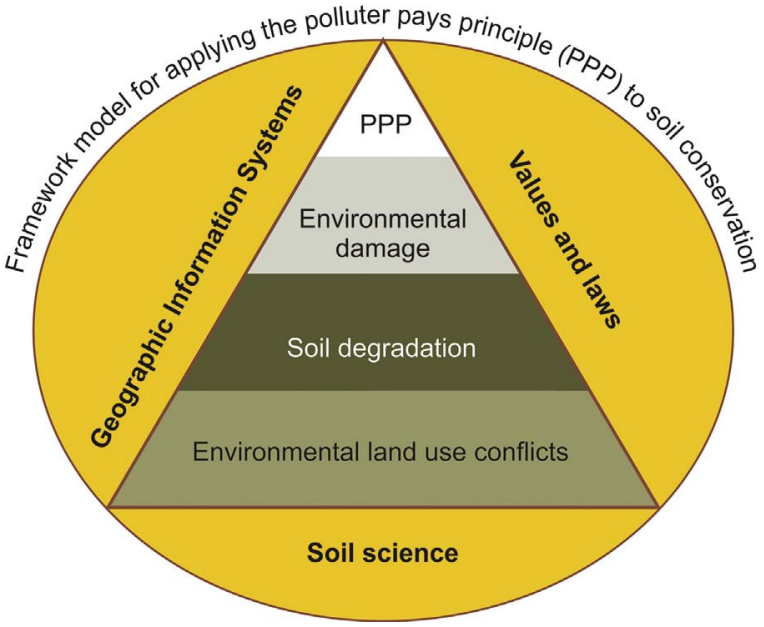

Fig. 9. - Framework model for applying the polluter pays principle to soil conservation.

previous section, remote sensing techniques coupled with geographic information systems support the diagnosis of human-related acceleration of soil erosion, namely ahead of acceptable values, with a presumed cascade of associated environmental impacts. In this case, it is reasonably clear that one may be facing an environmental damage, so the principle to apply is prevention whereby the protagonists are called up on to assume responsibility for the potential injury they might have caused. It is, however, mandatory to enforce the legislation as to avoid the limited efficiency of law application attained in antecedent examples. In this context, one can refer the deforestation and occupation of riparian vegetation buffers, called Permanent Protection Areas. This action may be considered a land use conflict potentially associated to environmental damages, namely to soil aridity, silting up of riverbeds and deterioration of freshwater quality and biodiversity. However, despite being legally protected by the Brazilian Forest Code (Federal Law no. 12651/2012), in the Uberaba River basin major portions of these buffers have been progressively occupied by pastures for livestock production (9121 ha) or crop agriculture (4652 ha), while the still preserved areas occupy just 5912 ha (Valle Junior et al., 2010b).

The best way to enforce responsibility of land owners as regards human-related soil loss acceleration is therefore to trigger a paradigm change whereby this condition is considered environmental degradation or pollution and judged from the standpoint of Federal Law no. $6938 / 81$, article $3^{\circ}$. In that context, when the process of natural erosion suffers anthropogenic action and consequently moves to the accelerated phase, it should be legally stated that it changes "to environmental degradation, which results in adverse changes to the environment, or to pollution that is defined as the environmental degradation that promotes direct or indirect harm to the health, safety and welfare of the population, creates adverse conditions for social and economic activities, and adversely affects biota and the aesthetic and sanitary conditions of the environment". The hypothesis of linking human-induced acceleration of soil erosion to the legal concepts of environmental degradation and pollution is further supported by the constitutional macro concept of environmental damage, defined as every harmful alteration to the environment. The law enforcement would be guaranteed by the statements of article $225^{\circ}$, paragraph 3, of Brazilian Federal Constitution of 1988, as well as by article $14^{\circ}$, paragraph 1 , of Federal Law no. 6938/81, which impose to direct and indirect protagonists of environmental damage the objective civil responsibility for the produced environmental illicit, providing that a causal link is demonstrated. It is worth recalling that objective responsibility is independent of will or guilt induced by negligence, mental disorder, imprudence or incompetence.

In summary, based on the identification and delimitation of land use conflicts, as well on the quantification of soil losses and their classification according to tolerances, it was concluded that a major portion of Uberaba River basin has been transformed into degraded land, a condition defined here as environmental damage. Based on the legal framework encompassing the polluter pays principle (Fig. 9), it is therefore possible to enforce land owners with the objective responsibility of repairing the damage. For the objective definition of land use conflicts and their objective association to intolerable soil losses, the use of Geographic Information Systems and soil loss models was crucial. 


\section{Conclusions}

The relationship between soil losses and environmental land use conflicts shows that conflicts may be an important source of soil loss increment in a watershed. In the Uberaba River basin (area: $2419 \mathrm{~km}^{2}$ ), located in the Triângulo Mineiro Region, state of Minas Gerais, Brazil, soil losses in non conflict areas were estimated as $24.5 \mathrm{tha}^{-1} \mathrm{y}^{-1}$ (classified as moderate) and in conflict areas as $55.0 \mathrm{tha}^{-1} \mathrm{y}^{-1}$ (i.e., two times higher, classified as high). Soil losses have been estimated using the Universal Soil Loss Equation and land use conflicts on the basis of a comparison between actual land uses and land capability set up by a morphometric parameter (the ruggedness number). Land use in the studied region is dominated by sugar cane plantations and pastures used for livestock production. Due to an improper use of land over decades, the coverage by areas where soil loss exceeded the tolerance limit reached $960.3 \mathrm{~km}^{2}$, which means $40 \%$ of the basin. In less than a decade (period 2008-2014), the areas occupied by intolerable soil losses increased 6\%, which represents an unsustainable increment rate of $\approx 1 \%$ per year. Soils being eroded at rates clearly above the tolerance thresholds are said degraded and usually trigger a cascade of environmental impacts with severe economic and social consequences, namely drop of soil productivity (and hence crop production), amplification of nutrient exports towards water masses ultimately resulting in water quality degradation, eutrophication and biodiversity decline. Overall, these impacts are legally viewed as environmental damage and provide the basis for setting up a causal link between conflicts (the cause) and damage (the effect). In line with the polluter pays principle, the protagonists of land use conflicts are legally and objectively responsible for the damages and should bear the associated repair costs. If applied at widespread scale, the polluter pays principle would constitute a new paradigm in soil use politics. To be implemented in practice, however, the aforementioned principle requires scientific and technological assistance. The combined use of USLE, soil tolerance models and Geographic Information Systems allow precise identification of degraded areas and thereby the objective application of the polluter pays principle, after field confirmation of soil degradation.

\section{Acknowledgements}

For authors integrated in the CITAB research center, the research was financed by the FEDER/COMPETE/POCI- Operational Competitiveness and Internationalization Programme, under Project POCI-01-0145-FEDER-006958, and by National Funds of FCTPortuguese Foundation for Science and Technology, under the project UID/AGR/04033/2013. For the author integrated in the CQVR research center, the research was supported by National Funds of FCT-Portuguese Foundation for Science and Technology, under the project UID/QUI/00616/2013.

\section{References}

Abuelaish, B., Olmedo, M.T.C., 2016. Scenario of land use and land cover change in the Gaza Strip using remote sensing and GIS models. Arabian J. Geosci. 9 (4), 1-14.

Agroconsultores Ltd., Coba Ltd, 1991. Carta de solos, carta do uso actual da terra e carta de aptidão da terra do nordeste de Portugal, scale 1:100 000. Trás-os-Montes and Alto Douro University, Vila Real, Portugal Digital base available at http://scrif.igeoe.pt.

Amorim, R.S.S., Silva, D.D., Pruski, F.F., Matos, A.T., 2010. Avaliação do desempenho dos modelos de predição da erosão hídrica USLE, RUSLE e WEPP para diferentes condições edafoclimáticas do Brasil, vol. 30. Engenharia Agrícola, Jaboticabal, pp. 1046-1049 (6).

Barati, A.A., Asadi, A., Kalantari, K., Azadi, H., Witlox, F., 2015. Agricultural land conversion in northwest Iran. Int. J. Environ. Res. 9 (1), 281-290.

Barretto, A.G.O.P., Lino, J.S., Sparovek, G., 2009. Bibliometria da pesquisa brasileira em erosão acelerada do solo: instituiç̃es, temas, espaço e cronologia. Revista Brasileira de Ciência do Solo 33, 1845-1854.

Bertoni, J., Lombardi Neto, F., 1999. Conservação do solo, 4ed). Ícone, Campinas, Brazil, pp. 355 p.

Borrelli, P., Paustian, K., Panagos, P., Jones, A., Schütt, B., Lugato, E., 2016. Effect of good agricultural and environmental conditions on erosionand soil organic carbon balance: a national case study. Land Use Policy 50, 408-421.
Bradley, D., Grainger, A., 2004. Social resilience as a controlling influence on desertification in Senegal. Land Degrad. Dev. 15, 451-470.

Conforti, M., Buttafuoco, G., Leone, A.P., Aucelli, A.P.P., Robustelli, G., Scarciglia, F., 2013. Studying the relationship between water-induced soil erosion and soil organic matter using Vis-NIR spectroscopy and geomorphological analysis: a case study in southern Italy. Catena 110, 44-58.

Cruz, L.B.S., 2003. Diagnóstico ambiental da bacia hidrográfica do rio Uberaba-MG (PhD Thesis in Agronomy in Agricultural Engineering). State University of Campinas, Campinas, Brazil $182 \mathrm{pp}$

D’Odorico, P., Bhattachan, A., Davis, K.F., Ravi, S., Runyan, C.W., 2013. Global desertification: drivers and feedbacks. Adv. Water Resour. 51, 326-344.

Dalmas, F.B., Oliveira, F.R., Silva, I.S., Santos, A.J., Filho, Paranhos, Arlei Benedito, A.C. Macedo, A.B., 2015. Development and assessment of an erosion and landslide predictive model for the coastal region of the State of São Paulo, Brazil. Pesquisas em Geociências 42 (2), 173-186.

De la Rosa, D., Moreno, J.A., Mayol, F., Bonsón, T., 2000. Assessment of soil erosion vulnerability in Western Europe and potential impact on crop productivity due to loss of soil depth using the ImpelERO model. Agric. Ecosyst. Environ. 81 (3), 179-190.

Demarchi, J.C., Zimback, C.R.L., 2014. Mapeamento, erodibilidade e tolerância de perda de solo na sub-bacia do Ribeirão das Perobas. Energia na Agricultura 29 (2), $102-114$.

Denardin, J.E., 1990. Erodibilidade Do Solo Estimada Por Meio De Parâmetros físicos E Químicos. PhD Thesis in Soils and Nutrition of Plants. University of São Paulo, College of Agriculture, Piracicaba, São Paulo Brazil.

Eastman, J.R., 2012. IDRISI Selva Manual. Clark Labs., Clark University, Worcester, MA 322 p. (Provided as a PDF with the IDRISI Selva software package).

Embrapa, 1982. Levantamento de reconhecimento de média intensidade dos solos e avaliação da aptidão agrícola das terras do Triangulo Mineiro. Boletim de Pesquisa, vol. 1 EPAMIG — RNR, Rio de Janeiro 526 p.

Embrapa, 1999. Sistema Brasileiro De Classificação De Solos. Centro Nacional de Pesquisa de Solos, Rio de Janeiro, Brasil.

Embrapa, 2006. Sistema Brasileiro De Classificação De Solos, 2 ed. Centro Nacional de Pesquisa de Solos, Rio de Janeiro, Brasil.

Foster, G.R., Mccool, D.K., Renard, K.G., Moldenhauer, W.C., 1981. Conversion of the universal soil loss equation to SI metric units. J. Soil Water Conserv. 36, 355-359.

Freitas, P.L., Landers, J.N., 2014. The transformation of agriculture in Brazil through development and adoption of Zero Tillage Conservation Agriculture. Int. Soil Water Conserv. Res. 2 (1), 35-46.

Golmohammadi, F., 2013. Desertification through rural people participation (Experience of International Project of Carbon Sequestration in South Khorasan Province-East of Iran). Procedia Technol. 8, 530-535.

Horton, R., 1945. Erosional development of streams and their drainage basins: hidrophysical approach to quantitative morphology. Geol. Soc. Am. Bull. 56, 807-813.

Lal, R., Moldenhauer, W.C., 1987. Effects of soil erosion on crop productivity. Crit. Rev. Plant Sci. 5 (4), 303-367.

Leighton, M., 2006. Desertification and migration. In: Johnson, Mayrand, Paquin (Eds.), Governing Global Desertification-- Linking Environmental Degradation, Poverty and Participation. Ashgate Publishing Limited, England.

Lepsch, I.F., 2002. Formação e Conservação dos Solos. Oficina dos Textos, Brazil.

Liu, R., Zhao, H., Zhao, X., 2011. Desertification impact on macro-invertebrate diversity in grassland soil in Horqin: Northern China. Procedia Environ. Sci. 10, 1401-1409.

Martín-Fernández, L., Martínez-Núñez, M., 2011. An empirical approach to estimate soil erosion risk in Spain. Sci. Total Environ. 409, 3114-3123.

Oliveira, F.P., 2004. Determinação da tolerância de perdas por erosão para as principais Ordens de solos do Estado da Paraíba. Graduation thesis in Agronomic Engineering. Federal University of Paraíba, Areia, Brazil, pp. 92p.

Pacheco, F.A.L., Landim, P.M.B., 2005. Two-way regionalized classification of multivariate data sets and its application to the assessment of hydrodynamic dispersion. Math. Geol. 37 (4), 393-417.

Pacheco, F.A.L., Sanches Fernandes, L.F., 2016. Environmental land use conflicts in catchments: a major cause of amplified nitrate in river water. Sci. Total Environ. 548-549, 173-188.

Pacheco, F.A.L., Van der Weijden, C.H., 2012a. Weathering of plagioclase across variable flow and solute transport regimes. J. Hydrol. 420-421, 46-58.

Pacheco, F.A.L., Van der Weijden, C.H., 2012b. Integrating topography, hydrology and rock structure in weathering rate models of spring watersheds. J. Hydrol. 428-429, 32-50.

Pacheco, F.A.L., Van der Weijden, C.H., 2014a. Role of hydraulic diffusivity in the decrease of weathering rates over time. J. Hydrol. 512, 87-106.

Pacheco, F.A.L., Van der Weijden, C.H., 2014b. Modeling rock weathering in small watersheds. J. Hydrol. 513, 13-27.

Pacheco, F.A.L., Landim, P.M.B., Szocs, T., 2013. Anthropogenic impacts on mineral weathering: a statistical perspective. Appl. Geochem. 36, 34-48.

Pacheco, F.A.L., Varandas, S.G.P., Sanches Fernandes, L.F., Valle Junior, R.F., 2014. Soil losses in rural watersheds with environmental land use conflicts. Sci. Total Environ. 485-486, 110-120.

Pacheco, F.A.L., Pires, L.M.G.R., Santos, R.M.B., Sanches Fernandes, L.F., 2015a. Factor weighting in DRASTIC modeling. Sci. Total Environ. 505, 474-486.

Pacheco, F.A.L., Santos, R.M.B., Sanches Fernandes, L.F., Pereira, M.G., Cortes, R.M.V., 2015b. Controls and forecasts of nitrate fluxes in forested watersheds: a view over mainland Portugal. Sci. Total Environ. 537, 421-440.

Pimentel, D., Harvey, C., Resosudarmo, P., Sinclair, K., Kurz, D., McNair, M., Crist, S., Shpritz, L., Fitton, L., Saffouri, R., Blair, R., 1995. Environmental and economic costs of soil erosion and conservation benefits. Science 267 (5201), 1117-1123.

Renard, K.G., Foster, G.R., Weesies, G.A., McCool, D.K., Yoder, D.C., 1997. Predicting Soil 
Erosion by Water: a Guide to Conservation Planning with the Revised Universal Soil Loss Equation (RUSLE). Agriculture Handbook no. 703, USDA, Washington 407p. Rocha, J.S.M., Kurtz, S.M.J.M., 2001. Manual De Manejo Integrado De Bacias Hidrográficas. Editora da UFSM, Santa Maria, Brazil 282p.

Rysz, K., Janiszek, M., 2015. The industrial city and its structural changes in local plans on the example of Ruda Śląska, Poland. Environ. Socio-Econ. Stud. 3 (3), 29-36.

Sanches Fernandes, L.F., Seixas, F., Oliveira, P., Leitao, S., Moura, J., 2012 Climatechange impacts on nitrogen in a hydrographical basin in the northeast of Portugal. Fresenius Environ. Bull. 21 (12), 3643-3650.

Santos, R.M.B., Sanches Fernandes, L.F., Moura, J.P., Pereira, M.G., Pacheco, F.A.L. 2014. The impact of climate change, human interference, scale and modeling uncertainties on the estimation of aquifer properties and river flow components. J. Hydrol. 519, 1297-1314.

Santos, R.M.B., Sanches Fernandes, L.F, Pereira, M.G., Cortes, R.M.V., Pacheco, F.A.L., 2015a. Water resources planning for a river basin with recurrent wildfires. Sci. Total Environ. 526, 1-13.

Santos, R.M.B., Sanches Fernandes, L.F., Varandas, S.G.P., Pereira, M.G., Sousa, R., Teixeira, A., Lopes-Lima, M., Cortes, R.M.V., Pacheco, F.A.L., 2015b. Impacts of climate change and land-use scenarios on Margaritifera margaritifera, an environmental indicator and endangered species. Sci. Total Environ. 511, 477-488.

Sarlet, I.W., Fensterseifer, T., 2014. Princípios do Direito Ambiental. Editora Saraiva, São Paulo, Brazil.

Silva, A.M., Schulz, H.E., Camargo, P.B., 2003. Erosão e hidrossedimentologia em bacias hidrográficas. Rima, São Carlos, Brazil 138p.

Silva, A.M., Shulz, H.E., Camargo, P.B., 2007. Erosão e Hidrossedimentologia em bacias hidrográficas. RiMA, São Carlos 154p.

Silva, C.R., Souza, K.B., Furtado, W.F., 2013. Evaluation of the progress of intensive agriculture in the Cerrado Piauiense-Brazil. IERI Procedia 5, 51-58.

Stein, D.P., Donzelli, P.L., Gimenez, A.F., Ponçano, W.L., Lombardi Neto, F., 1987. Potencial de erosão laminar, natural e antrópico, na bacia do Peixe-Paranapanema. Simpósio Nacional de Controle de Erosão, São Paulo, Brazil, pp. 105-135.

Strahler, A.N., 1952. Hypsometric analysis of erosional topography. Geol. Soc. Am. Bull. $63,1117-1142$.

Valera, C., Valle Junior, R.F., Varandas, S.G.P., Sanches Fernandes, L.F., Pacheco, F.A.L., 2016. The role of environmental land use conflicts in soil fertility: a study on the
Uberaba River basin Brazil. Sci. Total Environ. 562, 463-473.

Valle Junior, R.F., Galbiatti, J.A., Martins Filho, M.V., Pissarra, T.C.T., 2010a. Potencial de erosão da bacia do Rio Uberaba. Engenharia Agrícola 30 897/5-908.

Valle Junior, R.F., Passos, A.O., Abdala, V.L., Ramos, T.G., 2010b. Determinação das áreas de preservação permanente na bacia hidrográfica do Rio Uberaba MG, utilizando o Sistema de Informação Geográfica (SIG). Global Sci. Technol. 3, 19-29.

Valle Junior, R.F., Galbiatti, J.A., Pissarra, T.C.T., Martins Filho, M.V., Siqueira, H.E., 2012. A erosividade das chuvas na Bacia do Rio Uberaba. Enciclopédia Biosfera 8, $1-15$.

Valle Junior, R.F., Galbiatti, J.A., Pissarra, T.C.T., Martins Filho, M.V., 2013. Diagnóstico do conflito de uso e ocupação do solo na Bacia do Rio Uberaba. Global Sci. Technol. 6, 40-52.

Valle Junior, R.F., Varandas, S.G.P., Sanches Fernandes, L.F., Pacheco, F.A.L., 2014a. Environmental land use conflicts: a threat to soil conservation. Land Use Policy 41, $172-185$.

Valle Junior, R.F., Varandas, S.G.P., Sanches Fernandes, L.F., Pacheco, F.A.L., 2014b. Groundwater quality in rural watersheds with environmental land use conflicts. Sci. Total Environ. 493, 812-827.

Valle Junior, R.F., Varandas, S.G.P., Pacheco, F.A.L., Pereira, V.R., Santos, C.F., Cortes, R.M.V., Sanches Fernandes, L.F., 2015. Impacts of land use conflicts on riverine ecosystems. Land Use Policy 43, 48-62.

Villela, S.M., Mattos, A., 1975. Hidrologia Aplicada. McGraw Hill do Brasil, São Paulo, Brasil.

Wijitkosum, S., 2012. Impacts of land use changes on soil erosion in Pa Deng Sub-district Adjacent Area of Kaeng Krachan National Park, Thailand. Soil Water Res. 7 (1), 10-17.

Wijitkosum, S., 2016. The impact of land use and spatial changes on desertification risk in degraded areas in Thailand. Sustain. Environ. Res. 26, 84-92.

Wischmeier, W.H., Smith, D.D., 1958. Rainfall energy and its relationships to soil loss. Trans. Am. Geophys. Union 39 (2), 285-291.

Wischmeier, W.H.E., Smith, D.D., 1978. Predicting Rainfall Erosion Losses: a Guide to Conservation Planning. Agriculture Handbook, vol. 537. USDA, Washington, pp. 58

Zhao, H.-L., Zhou, R.-L., Zhang, T.-H., Zhao, X.-Y., 2006. Effects of desertification on soil and crop growth properties in Horqin sandy cropland of Inner Mongolia, North China. Soil Tillage Res. 87 (2), 175-185. 